Article

\title{
Combining the Conservation of Biodiversity with the Provision of Ecosystem Services in Urban Green Infrastructure Planning: Critical Features Arising from a Case Study in the Metropolitan Area of Rome
}

\author{
Giulia Capotorti, Eva Del Vico *, Ilaria Anzellotti and Laura Celesti-Grapow \\ Department of Environmental Biology, Sapienza University of Rome, P.le Aldo Moro 5, 00185 Rome, Italy; \\ giulia.capotorti@uniroma1.it (G.C.); ilaria.anzellotti@uniroma1.it (I.A.); laura.celesti@uniroma1.it (L.C.-G.) \\ * Correspondence: eva.delvico@uniroma1.it; Tel.: +39-06-4991-2420
}

Academic Editors: Karsten Grunewald and Olaf Bastian

Received: 5 August 2016; Accepted: 15 December 2016; Published: 23 December 2016

\begin{abstract}
A large number of green infrastructure (GI) projects have recently been proposed, planned and implemented in European cities following the adoption of the GI strategy by the EU Commission in 2013. Although this policy tool is closely related to biodiversity conservation targets, some doubts have arisen as regards the ability of current urban GI to provide beneficial effects not only for human societies but also for the ecological systems that host them. The aim of this work is to review the features that should be considered critical when searching for solutions that simultaneously support biodiversity and guarantee the provision of ecosystem services (ES) in urban areas. Starting from a case study in the metropolitan area of Rome, we highlight the role of urban trees and forests as proxies for overall biodiversity and as main ecosystem service providers. We look beyond the individual functional features of plant species and vegetation communities to promote the biogeographic representativity, ecological coherence and landscape connectivity of new or restored GI elements.
\end{abstract}

Keywords: biogeographic representativity; connectivity; ecological coherence; European Green Infrastructure Strategy; urban forests; urban trees

\section{Introduction}

The European GI Strategy defines green infrastructure (GI) as a "strategically planned network of natural and semi-natural areas with other environmental features designed and managed to deliver a wide range of ecosystem services" [1]. GI consists of "spatially or functionally connected areas which maintain ecological coherence as an essential condition for healthy ecosystems", and contemporarily presents an added value that derives from the potential to attract investments in natural capital to strengthen the ability of ecosystems to deliver multiple goods and services that benefit human societies [2].

Since its adoption in 2013, the European GI Strategy has attracted great interest across EU Member States, stimulating the proposal, planning and implementation of a large number of GI projects at both the landscape and the local scale [3], with the latter involving above all urban and peri-urban areas [4-7]. Unlike landscape scale designs in rural settings, those conceived for local scale GI in urban contexts have been addressed mainly at enhancing the provision of ecosystem services (ES) and the cost-effectiveness of such interventions, while considering the health of ecosystems, i.e., biodiversity in its multiple aspects, just a secondary and/or approximate goal $[5,8,9]$. This applies to several case studies that have focused on ways of greening grey infrastructures, e.g., by means of green roofs and green walls, or on increasing the provision of green spaces without considering the environmental setting within which the cities lie [10,11]. 
Theoretical frameworks that effectively incorporate biodiversity conservation into GI are being promoted to overcome these restrictions. They are drawing the attention of researchers, practitioners and decision-makers to structural and functional connectivity [12], to the quality of the surrounding urban matrix [13], to native biodiversity [14], and to species, habitats and ecosystems of conservation importance [15]. The need remains, however, to build the evidence base required to ensure that GI projects are effectively biodiversity-oriented and aptly fitted to local environments [16].

In keeping with an operational perspective, the aim of this work is to provide an overview of the concrete features that should be considered when searching for solutions that simultaneously support biodiversity and guarantee the supply of ES in urban areas. In particular, the results of this overview represent the basic ecological knowledge underlying the ongoing development of pilot urban GI projects in the metropolitan area of Rome. These projects have been commissioned by the Italian Ministry for the Environment to start implementing the European GI Strategy, and consequently the related Action 6 of the EU Biodiversity Strategy, at the national level. On the one hand, we provide an overview of the literature regarding the varying performance of urban forests and trees in ES provision; on the other hand, we highlight the evidence available regarding the features that play a critical role in the conservation of urban plant diversity. Accordingly, we also identify and discuss an array of different actions that allow plant diversity values and the provision of $\mathrm{ES}$ to be combined. The conclusions point to the actual and expected impact of these findings at the broader national and European levels.

\section{Materials and Methods}

As recently proposed for the implementation of the European Biodiversity Strategy for 2020 [17], actual vegetation cover can be considered as an effective operational proxy when outlining overall ecosystem complexity [18]. Concurrently, plant communities and plant species are widely recognized as being among the main providers of ES in urban areas, especially in the form of forests though also as isolated trees [19-21]. For these reasons, we analyzed specific features of trees and forests that may, besides being able to deliver multiple ES, be critical to the quality of natural and semi-natural ecosystems in urban contexts. The city of Rome, a metropolis in Mediterranean Europe, was adopted as a case study (Figure 1). The city covers an area of $345 \mathrm{~km}^{2}$ and represents the central urban sector of the municipality, which covers an area of approximately $1300 \mathrm{~km}^{2}$.

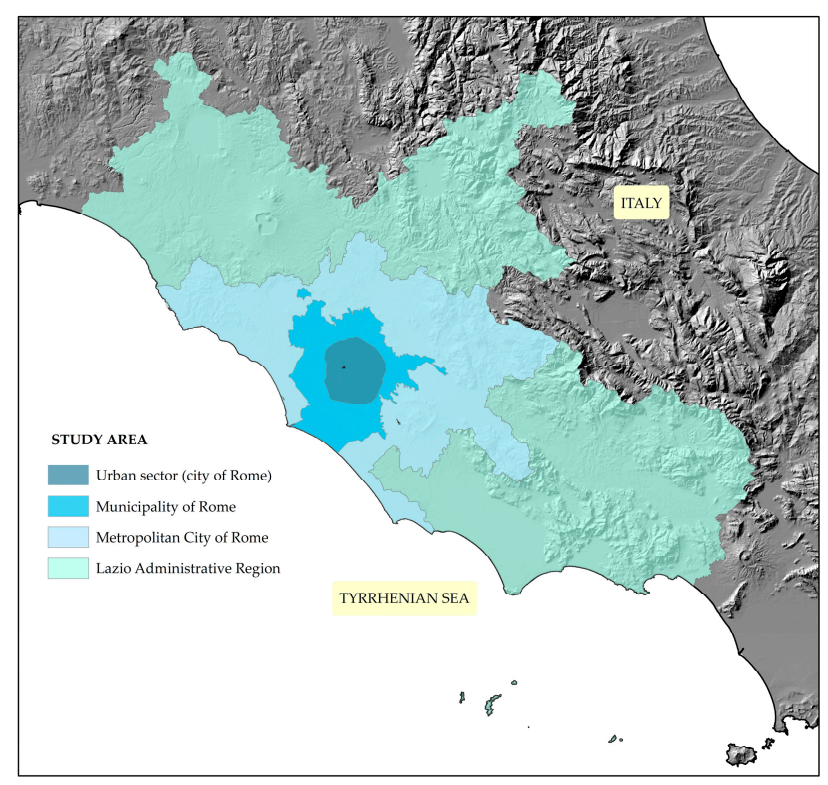

Figure 1. Study area. Location of the urban sector of Rome (central Italy) within the municipal, metropolitan and regional administrative boundaries. 
The overall approach adopted in the present work is shown in Figure 2.
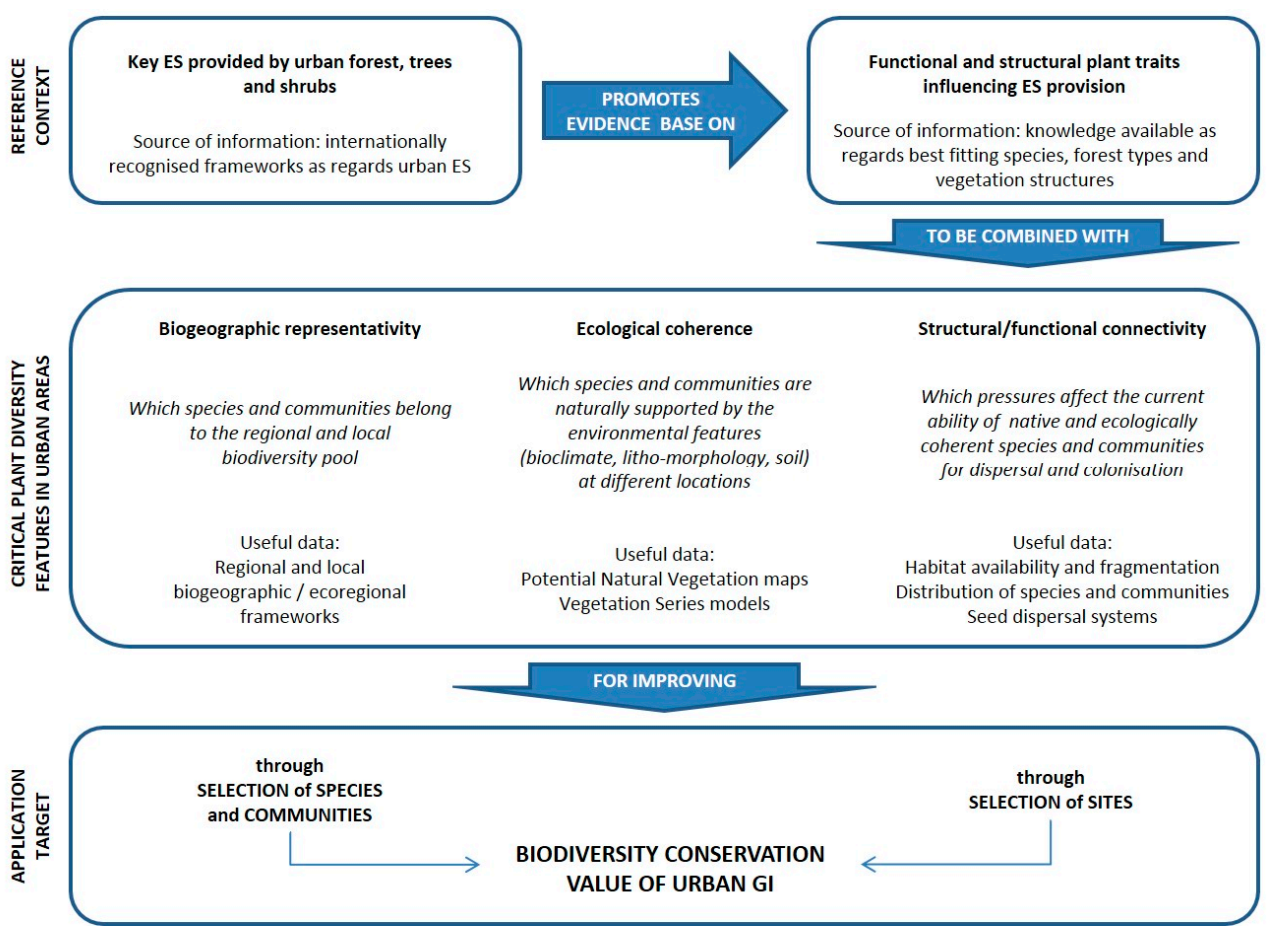

Figure 2. Overall approach adopted for the identification of biodiversity values that should be integrated into GI projects.

We first identified the ES framework of the research, and then searched for evidence of the functional and structural traits of urban trees and forest remnants that influence the provision of such ES in the scientific literature. As a reference framework for the key ES that are provided by urban forests and trees, we adopted the summary recently published for the mapping and assessment of urban ecosystems in Europe [4] (Table 1).

Table 1. Key ES totally or partially provided by woody vegetation in urban contexts (simplified from Maes et al. [4]). Sections and class types of ES refer to the international CICES (Common International Classification of Ecosystem Services) hierarchical classification system [22]. Providing units that are relevant to the present work are in bold.

\begin{tabular}{|c|c|c|}
\hline ES Section & Urban ES Class Type & Service Providing Unit \\
\hline \multirow{5}{*}{ Regulating } & Regulation of air quality & Forest, trees, shrubs \\
\hline & Climate regulation through reduction of $\mathrm{CO}_{2}$ & Vegetation, soil \\
\hline & Urban temperature regulation & $\begin{array}{l}\text { Forest, trees, shrubs, herbs, lawns, wetlands, } \\
\text { water bodies }\end{array}$ \\
\hline & Noise mitigation & Forest, trees, shrubs, vegetated surfaces \\
\hline & Water flow regulation and run-off mitigation & $\begin{array}{l}\text { Trees, shrubs, vegetated and permeable } \\
\text { surfaces }\end{array}$ \\
\hline \multirow{2}{*}{ Cultural } & Nature based recreation & \multirow{2}{*}{$\begin{array}{l}\text { Parks, gardens, forest, trees, agricultural } \\
\text { areas in the commuting zone, wetlands, water } \\
\text { bodies, waterways, Natura } 2000 \text { sites }\end{array}$} \\
\hline & Nature based education & \\
\hline
\end{tabular}

For each of the key ES listed in Table 1, we then performed an exploratory review of the scientific literature in order to find estimates of the capacity of different tree species and forest types to provide ES that may be relevant to our case study (Table 2). Specifically, references in Table 2 focus on 
studies that mainly considered woody species and forest types belonging to the flora and to the natural vegetation types of the city of Rome $[23,24]$, and/or that geographically involve the study area (Figure 1). The nomenclature of the species follows Conti et al. [25] for the native flora and Celesti-Grapow et al. [26] for the non-native flora.

Table 2. Information on the capacity of different woody species and forest types to provide ES and corresponding spatial level of the estimates.

\begin{tabular}{ll}
\hline Capacity to Provide ES & Spatial Level and Geographic Location of the Estimates Available \\
\hline $\begin{array}{l}\text { Air pollutant removal by different } \\
\text { physiognomic—structural vegetation categories }\end{array}$ & $\begin{array}{l}\text { Local level estimates for the administrative region and the } \\
\text { metropolitan area of Rome [27-29] }\end{array}$ \\
\hline $\begin{array}{l}\text { Carbon mitigation by different forest types and } \\
\text { tree species }\end{array}$ & $\begin{array}{l}\text { (a) National level estimates [30,31] and } \\
\text { (b) Local level estimates for the city of Rome [32,33] }\end{array}$ \\
\hline $\begin{array}{l}\text { Cooling effect by different tree species frequently } \\
\text { planted in cities }\end{array}$ & $\begin{array}{l}\text { (a) Local level estimates for various European cities [34-36] and } \\
\text { (b) Local level estimates for the city of Rome [32] }\end{array}$ \\
\hline $\begin{array}{l}\text { Ability of different vegetation structures and } \\
\text { hedgerow species to reduce noise levels }\end{array}$ & $\begin{array}{l}\text { (a) Local level estimates for North American cities [37,38] and } \\
\text { (b) Local level estimates for the city of Rome [39] }\end{array}$ \\
\hline $\begin{array}{l}\text { Influence on stormwater run-off and its rate of } \\
\text { discharge by different vegetation/tree canopy } \\
\text { cover types }\end{array}$ & Local level estimates for North American cities [40] \\
\hline $\begin{array}{l}\text { Development of people's identity, attachment to } \\
\text { natural environments, and increasing } \\
\begin{array}{l}\text { commitment toward nature protection by } \\
\text { different conservation/development urban zones }\end{array}\end{array}$ \\
\hline
\end{tabular}

In a second stage (Figure 2), we collected and integrated the wide range of information available on plant diversity for our case study, i.e., the urban sector of the city of Rome $[4,44]$. This information includes recent and updated inventories and distribution maps of plant species [23,44,45], forest ecosystems and habitats of conservation interest [43,46], and potential natural vegetation types [24]. On the basis of the scientific literature $[13,47,48]$ and of the knowledge available on drivers of biodiversity loss at the local level $[49,50]$, we then selected features that are critical to the enhancement and conservation of urban trees and forests.

Lastly, we provided original practical suggestions on how to integrate these biodiversity values into urban green infrastructure elements in the study area.

\section{Results}

\subsection{Ranking of the Performance of Urban Forests and Trees in ES Provision}

The estimates of the capacity of urban trees and forests to provide key ES that are listed in Table 2 display varying degrees of impact on the selection of species and sites that are deemed suited to GI interventions in the case study (Table 3).

As regards the cultural services, i.e., nature-based recreation and education (Table 3, item A), the literature only provides a coarse definition of the sectors of the city that should contemporarily: (i) develop pro-environmental concern, awareness and commitment for "nature" and biodiversity at the local and global level; (ii) promote the sense of continuity between urban and rural areas; and (iii) promote a collaboration between natural and social-behavioral sciences for a better urban and architectural planning of the city and increase people's positive relationship with urban green areas [43]. 
As regards the regulating services, evidence on noise mitigation (Table 3, item B1) was early collected both for the sites of intervention, which need to be as close as possible to the source of disturbance, and for vegetation structure, which should ideally consist of wide belts of tall, dense trees, or combinations of trees, shrubs and grasses, which are even more effective [37]. Moreover, evergreen species were deemed to perform better on account of their year-round noise screening qualities [37]. More in particular, an experimental study on the evergreen shrubs traditionally used for hedges in the city of Rome (Table 3, item B2) showed that, owing to their denser foliage and branches and higher leaf mass per unit of leaf area, species such as Pittosporum tobira and Laurus nobilis perform better than Pyracantha coccinea and Nerium oleander [39]. Laurus nobilis and Pyracantha coccinea are representative of the natural forest types of the study area, while Nerium oleander is typical of the islands and southernmost regions of Italy and Pittosporum tobira is a non-native species.

Table 3. Ranking of ES provision according to site and/or species and communities performance $(+++,++,+$ : relatively high, medium and low performance).

\begin{tabular}{|c|c|c|c|}
\hline \multirow{2}{*}{ ES Type } & \multicolumn{3}{|c|}{ Ranking According to SITE Performance } \\
\hline & +++ & ++ & + \\
\hline $\begin{array}{l}\text { A. Nature-based } \\
\text { recreation/education }\end{array}$ & $\begin{array}{l}\text { Sectors with a core function for } \\
\text { the combined conservation of } \\
\text { natural, agricultural and human } \\
\text { capital }\end{array}$ & $\begin{array}{l}\text { Sectors a with a connection function } \\
\text { between natural and urban systems }\end{array}$ & $\begin{array}{l}\text { Sectors suitable for innovative and } \\
\text { sustainable management strategies }\end{array}$ \\
\hline ES Type & \multicolumn{3}{|c|}{ Ranking According to SPECIES and COMMUNITIES Structure and/or Physiognomy Performance } \\
\hline B1. Noise mitigation & $\begin{array}{l}\text { Wide, tall and multi-stratified } \\
\text { vegetation belts with evergreen } \\
\text { species }\end{array}$ & & $\begin{array}{l}\text { Narrow, short and mono-stratified } \\
\text { vegetation belts with deciduous species }\end{array}$ \\
\hline B2. Noise mitigation & $\begin{array}{l}\text { Evergreen hedges with denser } \\
\text { foliage and branches and higher } \\
\text { leaf mass per unit of leaf area } \\
\text { (Pittosporum tobira and } \\
\text { Laurus nobilis) }\end{array}$ & & $\begin{array}{l}\text { Evergreen hedges with less dense foliage } \\
\text { and branches and lower leaf mass per } \\
\text { unit of leaf area (Pyracantha coccinea and } \\
\text { Nerium oleander) }\end{array}$ \\
\hline $\begin{array}{l}\text { D1. Urban temperature } \\
\text { regulation }\end{array}$ & $\begin{array}{l}\text { Trees with smaller leaves } \\
\text { (e.g., Robinia pseudoacacia, } \\
\text { Pinus sylvestris) in parks }\end{array}$ & & $\begin{array}{l}\text { Trees with larger leaves } \\
\text { (e.g., Acer platanoides, Aesculus } \\
\text { hippocastanum, Platanus hispanica) } \\
\text { along streets }\end{array}$ \\
\hline $\begin{array}{l}\text { D2. Urban temperature } \\
\text { regulation }\end{array}$ & $\begin{array}{l}\text { Trees with larger crown volume } \\
\text { (Quercus pubescens) }\end{array}$ & & $\begin{array}{l}\text { Trees with narrower crown volume } \\
\text { (Quercus ilex) }\end{array}$ \\
\hline $\begin{array}{l}\text { E1. Climate regulation } \\
\text { through reduction of } \mathrm{CO}_{2}\end{array}$ & $\begin{array}{l}\text { Quercus ilex forests } \\
\text { Exotic conifer forests } \\
\text { Deciduous oak forests } \\
\text { Fagus sylvatica forests } \\
\text { White fir/Norway spruce forests }\end{array}$ & $\begin{array}{l}\text { Castanea sativa forests } \\
\text { Hygrophilous broadleaved forests } \\
\text { Mediterranean pine forests } \\
\text { Mountain pine forests } \\
\text { Exotic broadleaved forests }\end{array}$ & $\begin{array}{l}\text { Bushlands } \\
\text { Mediterranean broadleaved } \\
\text { deciduous forests }\end{array}$ \\
\hline
\end{tabular}

The estimates for water flow regulation and run-off mitigation (Table 3, item C) only provide indications about the efficiency of different vegetation cover structures, regardless of their composition. The general recommendation is to increase canopy cover of the land surface [40].

As for the cooling effect related to the peculiar features of a site, a review of the available empirical evidence highlighted the positive role of size for urban parks [51]. With regard to species performance, Leuzinger et al. [34] showed that, at least in central European cities (Table 3, item D1), the crown temperatures of trees with smaller leaves, including conifers, tend to be lower than those of trees with larger leaves and, generally, that trees in parks are more efficient than trees surrounded by sealed 
ground. Only three of the species considered by the authors of that work, all of which displayed a medium or low performance, are native and naturally distributed in the administrative region that includes the city of Rome (Acer platanoides, Tilia cordata, Tilia platyphyllos), while one (Pinus sylvestris), whose performance is good, is a native species but has a biogeographic distribution that is restricted to the Alpine regions of the country, which lie far from the study area. All the others are non-native species that belong (Aesculus hippocastanum, Gleditsia triacanthos, Platanus hispanica, and Robinia pseudoacacia) or do not belong (Acer saccharinum, and Tilia tomentosa) to the flora of the city of Rome. Evidence regarding the performance of additional tree species that partly belong to the flora of the city of Rome also emerged from other European cities in the strictly Mediterranean or sub-Mediterranean climatic zone [35,36]. Specifically, the best performing species among those analysed in Thessaloniki [35] include a non-native species (Morus alba), a native species (Celtis australis) and a complex of species whose status is not unique to Rome (Platanus spp.). As the species set measured in that work does not fully represent the tree and forest diversity of Rome and no general consideration is provided regarding plant traits that mainly influence the thermal effect of different species, this ranking is not included in Table 3. At a more local level (Table 3, item D2), further indications related to two oak species that are native to the study area (Table 3, item D3) emerged for the city of Rome [32], with experimental evidence showing that in summer the deciduous oak Quercus pubescens performs better than the evergreen oak $Q$. ilex owing to its larger crown volume.

As regards both carbon mitigation and air pollutant removal, the indications that are available take into account the functionality of the different physiognomic types found in the case study and are consequently more specific.

The data available at the national level on carbon net primary productivity (Table 3, item E1) were considered as a proxy for carbon mitigation [30]. The ranking of physiognomic types that are characteristic of the urban sector of Rome points to a slightly better performance of evergreen oaks over exotic conifers and deciduous oaks, a medium performance of chestnut, hygrophilous broadleaves, Mediterranean pines and exotic broadleaves, and a minor potential contribution of bushlands and other Mediterranean deciduous broadleaves. Local estimates available at the tree species level (Table 3, item E2) for the native evergreen oak Quercus ilex, for the native deciduous oak Q. pubescens and for the introduced hybrid (native $\mathrm{x}$ non-native) broadleaved Platanus hispanica confirm the aforementioned ranking of the respective physiognomic types [33].

Lastly, local estimates for particulate matter removal (Table 3, item F1) indicate that conifer forests, Mediterranean maquis and evergreen oak forests perform better, per unit of forest cover, than chestnut, deciduous oaks and beech forests [29]. By contrast, deciduous species were found to contribute to tropospheric $\mathrm{O}_{3}$ removal per unit of forest cover to a greater extent than evergreen species (Table 3, item F2), though to a lesser extent than conifers [28].

\subsection{Critical Features for the Conservation of Urban Trees and Forests}

\subsubsection{Biogeographic Representativity and Ecological Coherence}

Since non-native species expand as urbanization increases and often represent an important component of urban ecosystems [52-54], we use the term "biogeographic representativity" to refer above all to the native status of species and communities.

Moreover, "locally contextualized biodiversity" is becoming increasingly important in approaches aimed at improving urban sustainability $[15,55,56]$. In this respect, the concept of biogeographic representativity may be applied up to the point at which the species that belong to the natural pool of the strict metropolitan area are distinguished from the overall group of native species.

At fine scales, biogeographic representativity further merges with the physical features of the environment in determining the species composition of natural communities. Therefore, we consider ecological coherence as species suitability for specific combinations of climatic, litho-morpholgical and edaphic conditions, i.e., coherence with the potential natural vegetation and related natural substitution 
communities $[57,58]$. As the natural bio-physical setting is never totally hidden by urbanization, even in the very center of cities $[59,60]$, and as native and ecologically coherent forests and trees grow well with little or no management [61,62], both biogeographic representativity and ecological coherence should be targeted for the conservation of biodiversity in urban regions [63].

In the area considered in this study, the baselines for biogeographic representativity and ecological coherence were ranked in multiple tiers by means of the incremental filtering of forest and tree pools from the regional to the city scale. As regards forest communities, a reference framework available for the Roman Area ecoregion includes 6 prevalent physiognomic types, 2 differential physiognomic types and 1 exclusive physiognomic type of vegetation potential belonging to the western Mediterranean, Italo-Tyrrhenian biogeographic province $[64,65]$. The prevalent and exclusive vegetation potential types consist of mixed communities dominated by deciduous oaks and of riparian woods, while the differential vegetation potential type consists of thermophilous beech forests that are typical of volcanic substrata in the ecoregion. In particular, the municipal area of Rome is characterized by 13 types of forest communities, nine of which occur in the restricted urban sector [44]; the urban forest communities include four types of deciduous and semi-deciduous oak woods that are characterized by a mixture of western and eastern Mediterranean and coastal Tyrrhenian and mountain Apennine biogeographic influences, four types of evergreen Mediterranean oak woods and five types of riparian and plain woods.

As regards woody species, 230 native taxa belong to the regional pool of the Lazio administrative region [66], which extends in longitude from the central Apennine chain to the central Tyrrhenian coast, ranges in altitude from sea level up to $2458 \mathrm{~m}$, and includes a large hilly sector. Seventy-nine species in this regional pool are representative of the vegetation potential of the municipal area of Rome, with 62 of these species occurring in the urban sector [44]. The woody species that do not reach the inner city are either restricted to the Mediterranean coastal sector of the municipality (e.g., Erica scoparia and Juniperus oxycedrus subsp. macrocarpa) or to the more mesophilous zones near the Apennine sector (e.g., Acer obtusatum and Sorbus torminalis). Interestingly, all the species of the genus Quercus that are characteristic of the most common types of potential natural vegetation in the whole municipality also occur in the urban sector. These species include: (i) evergreen oaks (Quercus ilex, and Q. suber), which have adapted to local arid conditions and draining substrata that are found in areas other than the coastal sector; (ii) thermophilous and hygrophilous deciduous oaks (Q. cerris, Q. frainetto, and Q. robur), which are typical of the macroscopic conditions of the area; and (iii) semi-deciduous oaks (Q. virgiliana, and $Q . x$ pseudosuber), which are characteristics of the Transitional zone between the Mediterranean and the Temperate bioclimatic regions $[67,68]$.

According to these baselines, we were able to highlight the following critical features of urban forest and tree diversity: (i) which forest and tree types found in the city are coherent with the natural potential at the different geographic levels; and (ii) the sites in which non-native trees and forests prevalently or exclusively represent the actual woody plant diversity, characterize the spontaneous recovery of woody vegetation, or hinder nature conservation in protected areas. Some examples of this evidence base are shown in Figure 3. 


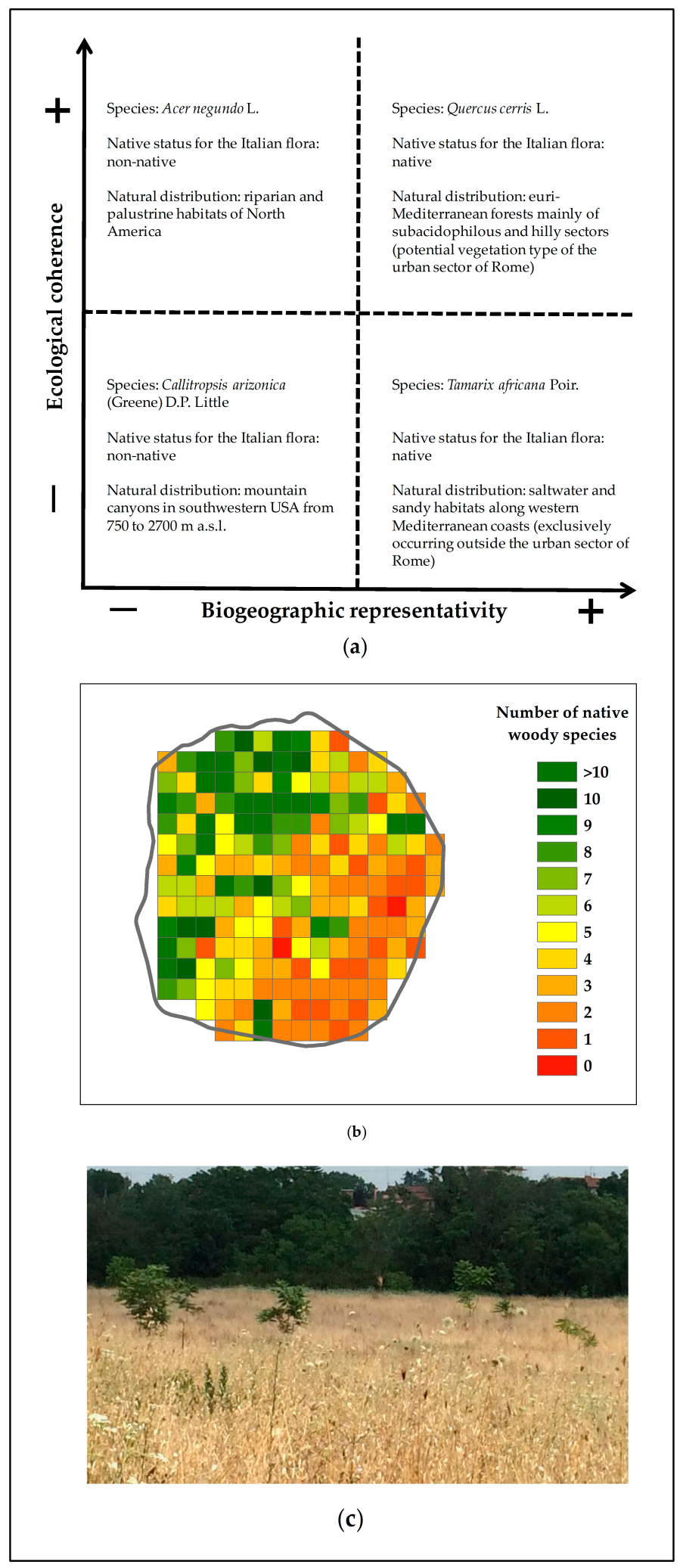

Figure 3. Examples of critical features of urban forest and tree diversity in the urban sector of Rome: (a) different biogeographic representativity and ecological coherence values for tree species that belong to the flora of the city [23,26,69-72]; (b) number of native woody species in the various sites according to the Atlas and to the inventory of the flora of Rome (cell size: $1.2 \mathrm{~km} \times 1.4 \mathrm{~km}$ ) [23,45]; and (c) non-native trees (Ailanthus altissima) that spontaneously recover an abandoned agricultural area in the Valle dell'Aniene Natural Reserve (central-eastern part of the city) (photo by Veridiana Barucci). 


\subsubsection{Structural and Functional Connectivity}

One of the main concerns regarding the persistence of urban biodiversity is the reduction, fragmentation and isolation of natural habitats and communities [73-75]. The effects of such pressure are usually recognized through structural connectivity measures that consider the spatial arrangement of remaining natural ecosystems in a transformed landscape mosaic [76,77]. Apart from the spatial proximity between natural patches, the level of connectivity between plants also depends on functional traits related to pollen and seed dispersal systems [78-80], which means the capacity to disperse over a prevalently artificial matrix is particularly important for plant diversity conservation in urban contexts.

Structural connectivity indicators for the overall municipal area of Rome revealed that evergreen and deciduous forests have become less isolated in recent decades [50]. This contrasts with the increasing isolation affecting other types of natural ecosystems, such as inland wetlands and beaches, dunes and sand plains [50]. However, compaction of artificial surfaces within the urban sector of Rome has severely impaired the functional connectivity of woody plants, particularly that of barochores (species dispersed by gravity) and of zoochores (species dispersed by animals), such as oaks.

Therefore, if combined with the lack of animal dispersal vectors that affect some of the urban sites [81], existing gaps in the distribution of species that are representative of the more widespread vegetation potentials have became a priority concern for biodiversity conservation (Figure 4).

\subsection{Suggested Actions for Integrating Biodiversity Values into Urban GI in the City of Rome}

The analysis of the tree and forest features that proved to be critical to the city of Rome led to the identification of a set of actions aimed at effectively integrating the conservation and/or restoration of biodiversity within multi-functional urban GI projects:

(1) Proactive conservation [82] of the native and spontaneous trees and forest remnants, focusing on those types that are most representative of the local potential natural vegetation. Although this action is markedly oriented toward biodiversity conservation, it always provides an expectedly positive balance between the delivery of maintenance, regulatory and cultural ES, and guarantees the long-term survival and low maintenance costs of the related GI components.

(2) Facilitation of the spontaneous natural dynamics, also defined as passive restoration [78], for the recovery of natural forest types in the various environmental units of the city. This GI intervention should generally be faster and less costly than active restoration measures and is expected to yield the same, well-balanced, multiple benefits as proactive conservation, without the risks involved in the planting of trees that do not fit in with the environmental conditions of the site. Moreover, if the size and the landscape context of the site permit it, a wider coverage area of ecologically coherent species and communities may enhance the GI-based delivery of regulating ES (as in the case of particulate matter removal) to a greater extent than a more limited number of trees that may perform better but that are ecologically incoherent (as in the case of evergreen oaks outside strictly Mediterranean-like environments).

(3) Control of the spread of non-native trees and replacement of exotic forests at specific sites, such as areas in which biogeographically representative and ecologically coherent woody plant diversity is poor, areas with a progressive vegetation dynamic that is prevalently based on non-native species, and protected areas. In such sites of the study area, the effort to recover native trees and forests should prevail over any other expected value of non-native species and communities related to the functional behavior and cost-effective introduction of the latter [47]. Therefore, this indication places some constraints on the open adoption of the best performing species and communities that are listed in Section 3.1 for the improvement of ES provision to desired levels.

(4) Active restoration of seed sources and enhancement of functional connectivity for biogeographically representative and ecologically coherent trees with critical gaps in their present distribution and short-distance dispersal. This action is particularly important in sites with poor native species diversity and a dense artificial matrix. In such markedly artificial environments, 
in which the focus is placed on GI elements that perform most effectively in elements such as noise abatement and/or air pollution removal, regardless of the type of ES providers, at least part of the areas being restored should be dedicated to the enhancement of functional connectivity between these woody species.

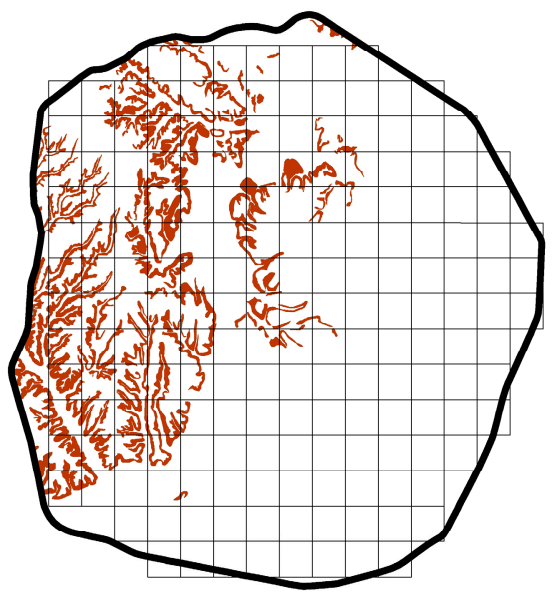

(a) Potential distribution of Quercus cerris forests with Q. frainetto

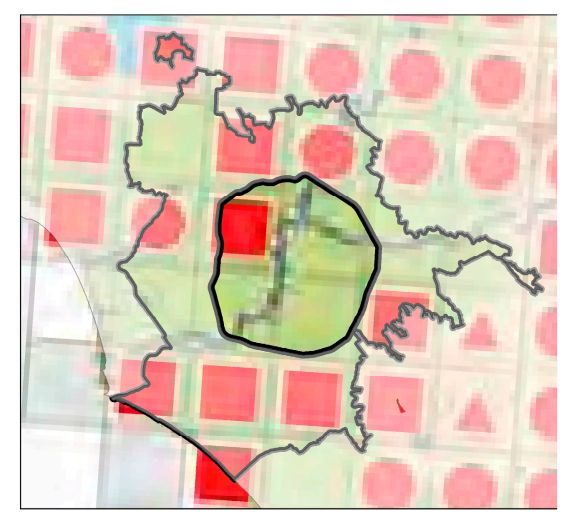

(c) Occurrence of bird dispersal vector

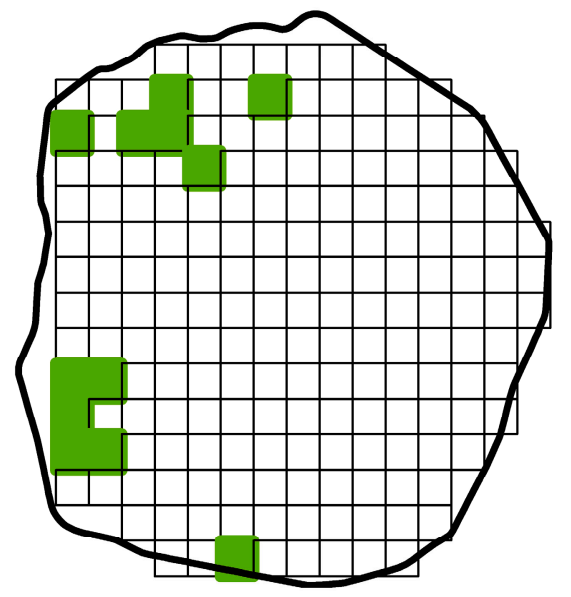

(b) Actual occurrence of Quercus frainetto

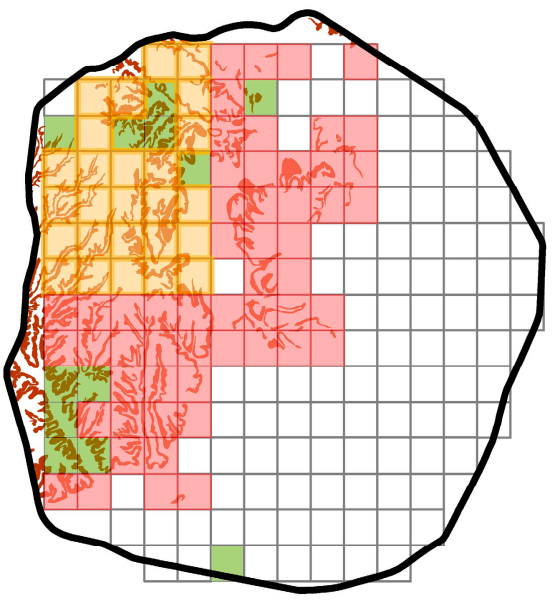

(d) Structural (orange cells) and functional (red cells) gaps in Quercus frainetto distribution

Figure 4. Identification of critical gaps in the distribution of a tree species (Quercus frainetto) that is representative of a vegetation natural potential type of the city of Rome (Quercus cerris and $Q$. frainetto forests on sandy hills slopes): (a) potential distribution of the species according to the natural environmental setting (data source: Map of the potential natural vegetation of Rome Municipality [24]); (b) actual distribution of the species in $1.2 \mathrm{~km} \times 1.4 \mathrm{~km}$ grid cells (data sources: Atlas and inventory of the flora of Rome [23,45]); (c) occurrence of a key bird dispersal vector for the species (Garrulus glandaria) in $10 \mathrm{~km} \times 10 \mathrm{~km}$ grid cells (data source: Atlas of the nesting birds of Lazio Region [81]; red squares = confirmed breeding; red circles = probable breeding; red triangles = possible breeding; empty cells = not found); and (d) identification of critical distribution gaps across the sites that may potentially host the species (cells with structural gaps = absence of the tree species despite favorable vegetation potential of the site; cells with functional gaps $=$ absence of both the tree species and the key bird dispersal vector despite favorable vegetation potential of the site). 


\section{Discussion and Conclusions}

The results of the present work provide a body of evidence that supports the inclusion of biodiversity issues in GI planning processes even within an urban context.

First, the approach adopted to select the estimates of the capacity of urban trees and forests to deliver key ES focuses on the geographic context of the research and on the components of biodiversity currently present in the study site.

On the one hand, the selection of estimates that prevalently refer to the regional, metropolitan, municipal or strictly urban area of the case study allows the widely acknowledged limitations of information transfer from different climatic, socio-economic and biogeographic contexts to be overcome [83-85]. This approach is in keeping with the urban ecology principle that is based on an integrated vision of cities and surrounding landscapes [86].

On the other hand, the explicit reference to the most comprehensive knowledge available on the spontaneous flora and natural vegetation of the city offers an effective tool for an informed selection of the species and communities to be planted, restored and/or conserved within an urban GI. In this regard, technical guidelines for the choice of sites and species in sustainable forestry have recently been outlined for the Municipality of Rome [87], and the present overview provides a set of reasoned scientific references that support these choices, including pivotal works, such as that on noise mitigation [37], more recent advances, such as that on urban temperature regulation [36], and local knowledge, such as that on air quality regulation [28]. Moreover, the synthesis of the estimates, as shown in Table 3, is also a useful tool for investigating inherent potential synergies and trade-offs (e.g., between evergreen and deciduous species/communities) according to approaches that have been developed to assess the multi-functional role of urban trees and forests (e.g., [88]). At the same time, it highlights which ES provision capacities are not strictly determined by species and community types, as in the case of water flow regulation and run-off mitigation. Moreover, it identifies the items for which further scientific evidence needs to be collected, as in the case of the delivery of cultural services, which are currently ranked merely according to different sites rather than to specific components of biodiversity This overview cannot, however, be considered exhaustive, particularly in view of the lack of a thorough assessment of trade-offs, otherwise defined as ecosystem disservices or costs [89-91]. Such trade-offs were not considered in this work because: (i) they usually require a finer, site-specific approach, as in the case of damage to infrastructures and monuments [92,93]; (ii) they rarely depend on the specific composition of the ecosystems, as in the case of negative attitudes displayed by inhabitants toward urban green areas [42]; and (iii) they are still controversial, as in the case of the balance between ozone removal and emission of volatile organic compounds by trees, which might increase ozone concentrations in the urban atmosphere [28].

Second, the analysis of features that are critical to biodiversity is based on a multi-scaled framework designed to assess the representativeness of the native vegetation. In addition, it fits into the combined structural and functional approach adopted to assess the role of connectivity in the persistence and resilience of biodiversity as well as in the subsequent capacity to provide ecosystem services [94,95].

The framework provides a tiered definition of vegetation potential and a baseline for the assessment of actual vegetation status that was previously used, in part, to select the priority sites and vegetation types for the municipal forestation program [96]. We now provide additional data that may help to enhance the synergies between ES provision and biodiversity conservation/restoration within a more comprehensive context of "biodiversity-led" [15] GI planning. With regard to the ultimate aim of GI projects and the desired ES provision, a different degree of consistency in terms of biogeographic representativeness and ecological coherence should, however, be expected [97]. Therefore, the various tiers allow the interventions to be assessed on a scale that ranges from markedly to weakly consistent (e.g., in terms of native status and degree of representativeness from the local to the regional scale), and may be defined as critical when inconsistent species and communities are expected to have strong negative impacts [98] on the layout of urban biodiversity (as in the cases shown in Figure 3). 
As regards connectivity, the evidence that emerges from the present work may be considered to be an initial step in improving the urban GI planning process in the city of Rome. This evidence provides some hints on which basic knowledge should be collected and combined to perform a comprehensive analysis of the issue, including the need to: (i) measure and monitor landscape connectivity in space and time [99], clearly distinguishing between the dynamics that affect the inner city from those that affect the suburban sectors [50]; (ii) recognize the functional traits of focal species [79]; and (iii) assess the spatial representation of both actual/potential distribution of plants and dispersal vectors. This information provides reliable information on the GI pilots in the study case, though its utility and applicability needs to be carefully investigated before it can be applied on a wider scale to other geographic contexts and cities of varying sizes that are characterized by different ecosystem pressures, conditions and spatial arrangements.

Third, the actions proposed here to integrate biodiversity values into urban GI in the city of Rome contribute to the field of research that addresses sustainability and resilience in urban GI design $[100,101]$. As a preparatory phase for follow-up projects, the suggestions follow a qualitative rather than a quantitative approach. Moreover, they prevalently concern patchy and linear components of GI (i.e., hubs and links sensu Benedict and McMahon [102]). The role of punctual features, such as green roofs and green walls, which are attracting an increasing amount of attention as potential tools for urban biodiversity conservation $[103,104]$, has not yet been considered. Notwithstanding these limitations, the evidence that emerges from our case study highlight elements that critically contribute to win-win and resilient solutions as regards biodiversity and ES provision (especially actions 1 and 2) and provide original indications that may be used to better define the ecological dimension of non-native plant management in cities (especially actions 3 and 4) [105,106].

In conclusion, we believe that the estimates of the capacities of urban trees and forests to provide key ES may help to select the most suitable species and communities for forestation programs and GI projects in cities. However, we do recognize that this selection often places excessive emphasis on ES delivery efficiency to the detriment of other features that are critical to the conservation and improvement of biodiversity values [20], thereby exposing biodiversity to certain risks, such as those identified by Garmendia et al. [8].

The present work represents a first step toward combining these two aspects through the provision of a set of evidence-based data for the effective, sustainable and resilient GI planning in the city of Rome. Although this evidence focuses on the urban trees and forests, and their respective features, found to be critical in the study area, it may be traced for any ecosystem components of urban GI as well as for other cities throughout the world.

The recommended actions that emerge from this study have been applied to pilot projects whose aim is to implement the GI strategy at the national level [18] and have been proposed at the European level within the context of the MAES Urban Pilot of the EU Commission [4]. Future research efforts will be made to fill the aforementioned existing gaps in knowledge, such as the need for a better definition of potential synergies and trade-offs between alternative urban forestry choices, a more comprehensive assessment of the complex cultural value of urban trees and forests, and a more in-depth investigation of the issue of ecological connectivity in urban contexts. Furthermore, a concerted effort to harmonize the proposed framework and the other findings that have emerged from numerous projects on GI planning and nature-based solution in Italian and European cities (e.g., $[15,16,107,108])$ will also be made in the near future.

Acknowledgments: This work was funded by Sapienza University of Rome (University Project 2015, prot. C26A15PLF2) and partially supported by the Italian Ministry for the Environment and the Protection of Land and Sea (MATTM).

Author Contributions: Giulia Capotorti conceived and designed the work and wrote the paper; Eva Del Vico and Ilaria Anzellotti processed the data; and Laura Celesti-Grapow coordinated the work and contributed to writing the paper.

Conflicts of Interest: The authors declare no conflict of interest. 


\section{References}

1. EC (European Commission). Communication from the Commission to the European Parliament, the Council, the European Economic and Social Committee and the Committee of the Regions 'Green Infrastructure (GI)_Enhancing Europe's Natural Capital' (COM(2013) 249 Final of 6 May 2013). Available online: http:/ / eur-lex.europa.eu/resource.html?uri=cellar:d41348f2-01d5-4abe-b817-4c73e6f1b2df.0014. 03/DOC_1\&format=PDF (accessed on 20 July 2016).

2. EEA (European Environment Agency). Spatial Analysis of Green Infrastructure in Europe; Technical Report No. 2/2014; Publications Office of the European Union: Luxembourg, 2014.

3. EEA (European Environment Agency). Green Infrastructure and Territorial Cohesion. The Concept of Green Infrastructure and Its Integration into Policies Using Monitoring Systems; EEA Technical Report No. 18/2011; Publications Office of the European Union: Luxembourg, 2011.

4. Maes, J.; Zulian, G.; Thijssen, M.; Castell, C.; Baró, F.; Ferreira, A.M.; Melo, J.; Garrett, C.P.; David, N.; Alzetta, C.; et al. Mapping and Assessment of Ecosystems and Their Services. Urban Ecosystems; Publications Office of the European Union: Luxembourg, 2016.

5. Lafortezza, R.; Davies, C.; Sanesi, G.; Konijnendijk, C.C. Green Infrastructure as a tool to support spatial planning in European urban regions. iForest 2013, 6, 102-108. [CrossRef]

6. Hansen, R.; Frantzeskaki, N.; McPhearson, T.; Rall, E.; Kabisch, N.; Kaczorowska, A.; Kain, J.H.; Artmann, M.; Pauleit, S. The uptake of the ecosystem services concept in planning discourses of European and American cities. Ecosyst. Serv. 2015, 12, 228-246. [CrossRef]

7. Andreucci, M.B. Progressing Green Infrastructure in Europe. WIT Trans. Ecol. Environ. 2013. [CrossRef]

8. Garmendia, E.; Apostolopoulou, E.; Adams, W.M.; Bormpoudakis, D. Biodiversity and Green Infrastructure in Europe: Boundary object or ecological trap? Land Use Policy 2016, 56, 315-319. [CrossRef]

9. Salomaa, A.; Paloniemi, R.; Kotiaho, J.S.; Kettunen, M.; Apostolopoulou, E.; Cent, J. Can green infrastructure help to conserve biodiversity? Environ. Plan. C Gov. Policy 2016, in press. [CrossRef]

10. Geneletti, D.; Zardo, L. Ecosystem-based adaptation in cities: An analysis of European urban climate adaptation plans. Land Use Policy 2016, 50, 38-47. [CrossRef]

11. Langemeyer, J.; Gómez-Baggethun, E.; Haase, D.; Scheuer, S.; Elmqvist, T. Bridging the gap between ecosystem service assessments and land-use planning through Multi-Criteria Decision Analysis (MCDA). Environ. Sci. Policy 2016, 62, 45-56. [CrossRef]

12. Pirnat, J.; Hladnik, D. Connectivity as a tool in the prioritization and protection of sub-urban forest patches in landscape conservation planning. Landsc. Urban Plan. 2016, 153, 129-139. [CrossRef]

13. Hostetler, M.; Allen, W.; Meurk, C. Conserving urban biodiversity? Creating green infrastructure is only the first step. Landsc. Urban Plan. 2011, 100, 369-371. [CrossRef]

14. Gagné, S.A.; Eigenbrod, F.; Bert, D.G.; Cunnington, G.M.; Olson, L.T.; Smith, A.C.; Fahrig, L. A simple landscape design framework for biodiversity conservation. Landsc. Urban Plan. 2015, 136, 13-27. [CrossRef]

15. Connop, S.; Vandergert, P.; Eisenberg, B.; Collier, M.J.; Nash, C.; Clough, J.; Newport, D. Renaturing cities using a regionally-focused biodiversity-led multifunctional benefits approach to urban green infrastructure. Environ. Sci. Policy 2016, in press.

16. Kremer, P.; Hamstead, Z.; Haase, D.; McPhearson, T.; Frantzeskaki, N.; Andersson, E.; Kabisch, N.; Larondelle, N.; Rall, E.; Voigt, A.; et al. Key insights for the future of urban ecosystem services research. Ecol. Soc. 2016. [CrossRef]

17. EC (European Commission). Communication from the Commission to the European Parliament, the Council, the Economic and Social Committee and the Committee of the Regions. Our Life Insurance, Our Natural Capital: An EU Biodiversity Strategy to 2020 (COM(2011)244 Final). Available online: http:/ / eur-lex.europa. eu/legal-content/EN/TXT/?uri=celex\%3A52011DC0244 (accessed on 20 July 2016).

18. Capotorti, G.; Alós Ortí, M.M.; Anzellotti, I.; Azzella, M.M.; Copiz, R.; Mollo, B.; Zavattero, L. The MAES process in Italy: Contribution of vegetation science to implementation of European Biodiversity Strategy to 2020. Plant Biosyst. 2015, 149, 949-953. [CrossRef]

19. Dobbs, C.; Escobedo, F.J.; Zipperer, W.C. A framework for developing urban forest ecosystem services and goods indicators. Landsc. Urban Plan. 2011, 99, 196-206. [CrossRef]

20. Roy, S.; Byrne, J.; Pickering, C. A systematic quantitative review of urban tree benefits, costs, and assessment methods across cities in different climatic zones. Urban For. Urban Green. 2012, 11, 351-363. [CrossRef] 
21. Baró, F.; Chaparro, L.; Gómez-Baggethun, E.; Langemeyer, J.; Nowak, D.J.; Terradas, J. Contribution of ecosystem services to air quality and climate change mitigation policies: The case of urban forests in Barcelona, Spain. Ambio 2014, 43, 466-479. [CrossRef] [PubMed]

22. EEA (European Environment Agency) CICES Website. Towards a Common Classification of Ecosystem Services. Available online: http:/ / cices.eu/ (accessed on 20 July 2016).

23. Celesti-Grapow, L.; Capotorti, G.; Del Vico, E.; Lattanzi, E.; Tilia, A.; Blasi, C. The vascular flora of Rome. Plant Biosyst. 2013, 147, 1059-1087. [CrossRef]

24. Blasi, C.; Capotorti, G. Carta Delle Serie di Vegetazione del Territorio del Comune di Roma $(1: 50,000)$. Available online: http:/ / www.urbanistica.comune.roma.it (accessed on 20 July 2016).

25. Conti, F.; Abbate, G.; Alessandrini, A.; Blasi, C. (Eds.) An Annotated Checklist of the Italian Vascular Flora; Palombi Editori: Rome, Italy, 2005.

26. Celesti-Grapow, L.; Alessandrini, A.; Arrigoni, P.V.; Banfi, E.; Bovio, M.; Brundu, G.; Cagiotti, M.; Camarda, I.; Bernardo, L.; Conti, F.; et al. Inventory of the non-native flora of Italy. Plant Biosyst. 2009, 143, 386-430. [CrossRef]

27. Manes, F.; Blasi, C.; Salvatori, E.; Capotorti, G.; Galante, G.; Feoli, E.; Incerti, G. Natural vegetation and ecosystem services related to air quality improvement: Tropospheric ozone removal by evergreen and deciduous forests in Latium (Italy). Ann. Bot. 2012, 2, 79-86.

28. Manes, F.; Incerti, G.; Salvatori, E.; Vitale, M.; Ricotta, C.; Costanza, R. Urban ecosystem services: Tree diversity and stability of tropospheric ozone removal. Ecol. Appl. 2012, 22, 349-360. [CrossRef] [PubMed]

29. Manes, F.; Marando, F.; Capotorti, G.; Blasi, C.; Salvatori, E.; Fusaro, L.; Ciancarella, L.; Mircea, M.; Marchetti, M.; Chirici, G.; et al. Regulating Ecosystem Services of forests in ten Italian Metropolitan Cities: Air quality improvement by $\mathrm{PM}_{10}$ and $\mathrm{O}_{3}$ removal. Ecol. Indic. 2016, 67, 425-440. [CrossRef]

30. Chirici, G.; Barbati, A.; Maselli, F. Modelling of Italian forest net primary productivity by the integration of remotely sensed and GIS data. For. Ecol. Manag. 2007, 246, 285-295. [CrossRef]

31. Marchetti, M.; Sallustio, L.; Ottaviano, M.; Barbati, A.; Corona, P.; Tognetti, R.; Zavattero, L.; Capotorti, G. Carbon sequestration by forests in the National Parks of Italy. Plant Biosyst. 2012, 146, 1001-1011. [CrossRef]

32. Gratani, L.; Varone, L. Carbon sequestration by Quercus ilex L. and Quercus pubescens Willd. and their contribution to decreasing air temperature in Rome. Urban Ecosyst. 2006, 9, 27-37. [CrossRef]

33. Gratani, L.; Varone, L. Plant crown traits and carbon sequestration capability by Platanus hybrida Brot. in Rome. Landsc. Urban Plan. 2007, 81, 282-286. [CrossRef]

34. Leuzinger, S.; Vogt, R.; Körner, C. Tree surface temperature in an urban environment. Agric. For. Meteorol. 2010, 150, 56-62. [CrossRef]

35. Georgi, N.J.; Zafiriadis, K. The impact of park trees on microclimate in urban areas. Urban Ecosyst. 2006, 9, 195-209. [CrossRef]

36. Napoli, M.; Massetti, L.; Brandani, G.; Petralli, M.; Orlandini, S. Modeling tree shade effect on urban ground surface temperature. J. Environ. Qual. 2016, 45, 146-156. [CrossRef] [PubMed]

37. Cook, D.I.; van Haverbeke, D.F. Trees and Shrubs for Noise Abatement; Experimental Station Bulletin; University of Nebraska, College of Agricultural: Lincoln, NE, USA, 1971; Volume 246.

38. Nowak, D.J.; Dwyer, J.F. Understanding the benefits and costs of urban forest ecosystems. In Urban and Community Forestry in the Northeast; Springer: Dordrecht, The Netherlands, 2007; pp. 25-46.

39. Gratani, L.; Varone, L. Carbon sequestration and noise attenuation provided by hedges in Rome: The contribution of hedge traits in decreasing pollution levels. Atmos. Pollut. Res. 2013, 4, 315-332. [CrossRef]

40. Sanders, R.A. Urban vegetation impacts on the hydrology of Dayton, Ohio. Urban Ecol. 1986, 9, 361-376. [CrossRef]

41. Bonaiuto, M.; Fornara, F.; Bonnes, M. Indexes of perceived residential environment quality and neighbourhood attachment in urban environments: A confirmation study on the city of Rome. Landsc. Urban Plan. 2003, 65, 41-52. [CrossRef]

42. Bonnes, M.; Carrus, G.; Bonaiuto, M.; Fornara, F.; Passafaro, P. Inhabitants' environmental perceptions in the city of Rome within the framework of Urban Biosphere Reserves of the UNESCO programme on Man and Biosphere. Ann. N. Y. Acad. Sci. 2004, 1023, 175-186. [CrossRef] [PubMed]

43. Blasi, C.; Capotorti, G.; Marchese, M.; Marta, M.; Bologna, M.A.; Bombi, P.; Bonaiuto, M.; Bonnes, M.; Carrus, G.; Cifelli, F.; et al. Interdisciplinary research for the proposal of the Urban Biosphere Reserve of Rome Municipality. Plant Biosyst. 2008, 142, 305-312. [CrossRef] 
44. Capotorti, G.; Del Vico, E.; Lattanzi, E.; Tilia, A.; Celesti-Grapow, L. Exploring biodiversity in a metropolitan area in the Mediterranean region: The urban and suburban flora of Rome (Italy). Plant Biosyst. 2013, 147, 174-185. [CrossRef]

45. Celesti-Grapow, L. Atlante della Flora di Roma; Comune di Roma: Rome, Italy, 1995.

46. Blasi, C.; Lattanzi, E.; Tilia, A.; Celesti-Grapow, L.; Fortini, P.; Capotorti, G. Carta Delle Emergenze Floristico-Vegetazionali del Territorio del Comune di Roma (1:20,000). Available online: http://www. urbanistica.comune.roma.it (accessed on 20 July 2016).

47. Dearborn, D.C.; Kark, S. Motivations for conserving urban biodiversity. Conserv. Biol. 2009, 24, 432-440. [CrossRef] [PubMed]

48. Kowarik, I. Novel urban ecosystems, biodiversity, and conservation. Environ. Pollut. 2011, 159, $1974-1983$. [CrossRef] [PubMed]

49. Celesti-Grapow, L.; Di Marzio, P.; Blasi, C. The importance of alien and native species in the urban flora of Rome (Italy). In Plant Invasions: Species Ecology and Ecosystem Management; Brundu, G., Brock, J., Camarda, I., Child, L., Wade, M., Eds.; Blackhuys Publ.: Leiden, The Netherlands, 2001; pp. 209-220.

50. Frondoni, R.; Mollo, B.; Capotorti, G. A landscape analysis of land cover change in the Municipality of Rome (Italy): Spatio-temporal characteristics and ecological implications of land cover transitions from 1954 to 2001. Landsc. Urban Plan. 2011, 100, 117-128. [CrossRef]

51. Bowler, D.E.; Buyung-Ali, L.; Knight, T.M.; Pullin, A.S. Urban greening to cool towns and cities: A systematic review of the empirical evidence. Landsc. Urban Plan. 2010, 97, 147-155. [CrossRef]

52. McKinney, M.L. Urbanization as a major cause of biotic homogenization. Biol. Conserv. 2006, 127, $247-260$. [CrossRef]

53. Trentanovi, G.; Lippe, M.; Sitzia, T.; Ziechmann, U.; Kowarik, I.; Cierjacks, A. Biotic homogenization at the community scale: Disentangling the roles of urbanization and plant invasion. Divers. Distrib. 2013, 19, 738-748. [CrossRef]

54. Aronson, M.F.; Handel, S.N.; La Puma, I.P.; Clemants, S.E. Urbanization promotes non-native woody species and diverse plant assemblages in the New York metropolitan region. Urban Ecosyst. 2015, 18, 31-45. [CrossRef]

55. Ricotta, C.; Di Nepi, M.; Guglietta, D.; Celesti-Grapow, L. Exploring taxonomic filtering in urban environments. J. Veg. Sci. 2008, 19, 229-238. [CrossRef]

56. Pärtel, M.; Bennett, J.A.; Zobel, M. Macroecology of biodiversity: Disentangling local and regional effects. New Phytol. 2016, 211, 404-410. [CrossRef] [PubMed]

57. Blasi, C.; Capotorti, G.; Frondoni, R. Defining and mapping typological models at the landscape scale. Plant Biosyst. 2005, 139, 155-163. [CrossRef]

58. Capotorti, G.; Guida, D.; Siervo, V.; Smiraglia, D.; Blasi, C. Ecological classification of land and conservation of biodiversity at the national level: The case of Italy. Biol. Conserv. 2012, 147, 174-183. [CrossRef]

59. Blasi, C.; Capotorti, G.; Marta, M.; Marchese, M. An integrated approach to better define the concept and functions of Urban Biosphere Reserves. Plant Biosyst. 2008, 142, 324-330. [CrossRef]

60. Bolund, P.; Hunhammar, S. Ecosystem services in urban areas. Ecol. Econ. 1999, 29, 293-301. [CrossRef]

61. Miyawaki, A. Restoration of living environment based on vegetation ecology: Theory and practice. Ecol. Res. 2004, 19, 83-90. [CrossRef]

62. Schirone, B.; Salis, A.; Vessella, F. Effectiveness of the Miyawaki method in Mediterranean forest restoration programs. Landsc. Ecol. Eng. 2011, 7, 81-92. [CrossRef]

63. Kenney, W.A.; van Wassenaer, P.J.E.; Satel, A.L. Criteria and Indicators for Strategic Urban Forest Planning and Management. Arboric. Urban For. 2011, 37, 108-117.

64. Blasi, C.; Capotorti, G.; Copiz, R.; Guida, D.; Mollo, B.; Smiraglia, D.; Zavattero, L. Classification and mapping of the ecoregions of Italy. Plant Biosyst. 2014, 148, 1255-1345. [CrossRef]

65. Rivas-Martínez, S.; Penas, A.; Díaz, T.E. Bioclimatic and Biogeographic Maps of Europe. Available online: http://www.globalbioclimatics.org/form/maps.htm (accessed on 20 July 2016).

66. Anzalone, B.; Iberite, M.; Lattanzi, E. La Flora vascolare del Lazio. Inform. Bot. Ital. 2010, 42, 187-317.

67. Blasi, C.; Carranza, M.L.; Filesi, L.; Tilia, A.; Acosta, A. Relation between climate and vegetation along a Mediterranean-Temperate boundary in central Italy. Glob. Ecol. Biogeogr. 1999, 8, 17-27. [CrossRef]

68. Viscosi, V.; Fortini, P.; Slice, D.E.; Loy, A.; Blasi, C. Geometric morphometric analyses of leaf variation in four oak species of the subgenus Quercus (Fagaceae). Plant Biosyst. 2009, 143, 575-587. [CrossRef] 
69. The IUCN Red List of Threatened Species 2016-1. Available online: www.iucnredlist.org (accessed on 20 July 2016).

70. Rosario, L.C. Acer Negundo. Fire Effects Information System. 1988. Available online: http://www.fs.fed.us/ database/feis/plants/tree/aceneg/all.html (accessed on 20 July 2016).

71. Maldonado, N.G.; López, M.J.; Caudullo, G. Tamarix-tamarisks in Europe: Distribution, habitat, usage and threats. In European Atlas of Forest Tree Species; San-Miguel-Ayanz, J., de Rigo, D., Caudullo, G., Houston Durrant, T., Mauri, A., Eds.; Publication Office of the European Union: Luxembourg, 2016.

72. De Rigo, D.; Enescu, C.M.; Durrant, T.H.; Caudullo, G. Quercus cerris in Europe: Distribution, habitat, usage and threats. In European Atlas of Forest Tree Species; San-Miguel-Ayanz, J., de Rigo, D., Caudullo, G., Houston Durrant, T., Mauri, A., Eds.; Publication Office of the European Union: Luxembourg, 2016.

73. Beninde, J.; Veith, M.; Hochkirch, A. Biodiversity in cities needs space: A meta-analysis of factors determining intra-urban biodiversity variation. Ecol. Lett. 2015, 18, 581-592. [CrossRef] [PubMed]

74. Maes, J.; Barbosa, A.; Baranzelli, C.; Zulian, G.; e Silva, F.B.; Vandecasteele, I.; Hiederer, R.; Liquete, C.; Paracchini, M.L.; Mubareka, S.; et al. More green infrastructure is required to maintain ecosystem services under current trends in land-use change in Europe. Landsc. Ecol. 2015, 30, 517-534. [CrossRef] [PubMed]

75. Kong, F.; Yin, H.; Nakagoshi, N.; Zong, Y. Urban green space network development for biodiversity conservation: Identification based on graph theory and gravity modeling. Landsc. Urban Plan. 2010, 95, 16-27. [CrossRef]

76. Calabrese, J.M.; Fagan, W.F. A comparison-shopper's guide to connectivity metrics. Front. Ecol. Environ. 2004, 2, 529-536. [CrossRef]

77. Van der Walt, L.; Cilliers, S.S.; Du Toit, M.J.; Kellner, K. Conservation of fragmented grasslands as part of the urban green infrastructure: How important are species diversity, functional diversity and landscape functionality? Urban Ecosyst. 2015, 18, 87-113. [CrossRef]

78. Benayas, J.M.R.; Bullock, J.M. Vegetation restoration and other actions to enhance wildlife in European agricultural landscapes. In Rewilding European Landscapes; Springer International Publishing: Cham (ZG), Switzerland, 2015; pp. 127-142.

79. Puerta-Piñero, C.; Pino, J.; Gómez, J.M. Direct and indirect landscape effects on Quercus ilex regeneration in heterogeneous environments. Oecologia 2012, 170, 1009-1020. [CrossRef] [PubMed]

80. Murphy, H.T.; Lovett-Doust, J. Context and connectivity in plant metapopulations and landscape mosaics: Does the matrix matter? Oikos 2004, 105, 3-14. [CrossRef]

81. Brunelli, M.; Sarrocco, S.; Corbi, F.; Sorace, A.; Boano, A.; De Felici, S.; Guerrieri, G.; Meschini, A.; Roma, S. Nuovo Atlante Degli Uccelli Nidificanti nel Lazio; Edizioni ARP (Agenzia Regionale Parchi): Rome, Italy, 2011.

82. Brooks, T.M.; Mittermeier, R.A.; da Fonseca, G.A.B.; Gerlach, J.; Hoffmann, M.; Lamoreux, J.F.; Mittermeier, C.G.; Pilgrim, J.D.; Rodrigues, A.S.L. Global biodiversity conservation priorities. Science 2006, 313, 58-61. [CrossRef] [PubMed]

83. Richardson, L.; Loomis, J.; Kroeger, T.; Casey, F. The role of benefit transfer in ecosystem service valuation. Ecol. Econ. 2015, 115, 51-58. [CrossRef]

84. Livesley, S.J.; McPherson, G.M.; Calfapietra, C. The Urban Forest and Ecosystem Services: Impacts on Urban Water, Heat, and Pollution Cycles at the Tree, Street, and City Scale. J. Environ. Qual. 2016, 45, 119-124. [CrossRef] [PubMed]

85. Norton, B.A.; Coutts, A.M.; Livesley, S.J.; Harris, R.J.; Hunter, A.M.; Williams, N.S. Planning for cooler cities: A framework to prioritise green infrastructure to mitigate high temperatures in urban landscapes. Landsc. Urban Plan. 2015, 134, 127-138. [CrossRef]

86. Pickett, S.T.; Cadenasso, M.L.; Grove, J.M.; Nilon, C.H.; Pouyat, R.V.; Zipperer, W.C.; Costanza, R. Urban ecological systems: Linking terrestrial ecological, physical, and socioeconomic components of metropolitan areas. Annu. Rev. Ecol. Syst. 2001, 32, 127-157. [CrossRef]

87. Mirabile, M.; Bianco, P.M.; Silli, V.; Brini, S.; Chiesura, A.; Vitullo, M.; Ciccarese, L.; De Lauretis, R.; Gaudioso, D. Guidelines of Sustainable Urban Forestry for the Municipality of Rome; ISPRA: Roma, Italy, 2015.

88. Tiwary, A.; Williams, I.D.; Heidrich, O.; Namdeo, A.; Bandaru, V.; Calfapietra, C. Development of multi-functional streetscape green infrastructure using a performance index approach. Environ. Pollut. 2016, 208, 209-220. [CrossRef] [PubMed]

89. Gómez-Baggethun, E.; Barton, D.N. Classifying and valuing ecosystem services for urban planning. Ecol. Econ. 2013, 86, 235-245. [CrossRef] 
90. Escobedo, F.J.; Kroeger, T.; Wager, J.E. Urban forest and pollution mitigation: Analyzing ecosystem services and disservices. Environ. Pollut. 2011, 159, 2078-2087. [CrossRef] [PubMed]

91. Lyytimäki, J.; Sipilä, M. Hopping on one leg-The challenge of ecosystem disservices for urban green management. Urban For. Urban Green. 2009, 8, 309-315. [CrossRef]

92. Celesti-Grapow, L.; Blasi, C. The role of alien and native weeds in the deterioration of archaeological remains in Italy. Weed Technol. 2004, 18, 1508-1513.

93. Caneva, G.; Pacini, A.; Celesti-Grapow, L.; Ceschin, S. The Colosseum's use and state of abandonment analysed through its flora. Int. Biodeterior. Biodegrad. 2003, 51, 211-219. [CrossRef]

94. Mitchell, M.G.; Bennett, E.M.; Gonzalez, A. Linking landscape connectivity and ecosystem service provision: Current knowledge and research gaps. Ecosystems 2013, 16, 894-908. [CrossRef]

95. Lechner, A.M.; Doerr, V.; Harris, R.M.; Doerr, E.; Lefroy, E.C. A framework for incorporating fine-scale dispersal behaviour into biodiversity conservation planning. Landsc. Urban Plan. 2015, 141, 11-23. [CrossRef]

96. Capotorti, G.; Mollo, B.; Zavattero, L.; Anzellotti, I.; Celesti-Grapow, L. Setting Priorities for Urban Forest Planning. A Comprehensive Response to Ecological and Social Needs for the Metropolitan Area of Rome (Italy). Sustainability 2015, 7, 3958-3976. [CrossRef]

97. Sjöman, H.; Morgenroth, J.; Sjöman, J.D.; Sæbø, A.; Kowarik, I. Diversification of the urban forest-Can we afford to exclude exotic tree species? Urban For. Urban Green. 2016, 18, 237-241. [CrossRef]

98. Dickie, I.A.; Bennett, B.M.; Burrows, L.E.; Nunez, M.A.; Peltzer, D.A.; Porté, A.; Richardson, D.M.; Rejmánek, M.; Rundel, P.W.; van Wilgen, B.W. Conflicting values: Ecosystem services and invasive tree management. Biol. Invasions 2014, 16, 705-719. [CrossRef]

99. Barbati, A.; Corona, P.; Salvati, L.; Gasparella, L. Natural forest expansion into suburban countryside: Gained ground for a green infrastructure? Urban For. Urban Green. 2013, 12, 36-43. [CrossRef]

100. Schewenius, M.; McPhearson, T.; Elmqvist, T. Opportunities for increasing resilience and sustainability of urban social-ecological systems: Insights from the URBES and the cities and biodiversity outlook projects. Ambio 2014, 43, 434-444. [CrossRef] [PubMed]

101. Childers, D.L.; Cadenasso, M.L.; Grove, J.M.; Marshall, V.; McGrath, B.; Pickett, S.T. An ecology for cities: A transformational nexus of design and ecology to advance climate change resilience and urban sustainability. Sustainability 2015, 7, 3774-3791. [CrossRef]

102. Benedict, M.A.; McMahon, E.T. Green Infrastructure; Island Press: Washington, DC, USA, 2006; pp. 1-299.

103. Williams, N.S.; Lundholm, J.; MacIvor, J.S. FORUM: Do green roofs help urban biodiversity conservation? J. Appl. Ecol. 2014, 51, 1643-1649. [CrossRef]

104. Madre, F.; Vergnes, A.; Machon, N.; Clergeau, P. Green roofs as habitats for wild plant species in urban landscapes: First insights from a large-scale sampling. Landsc. Urban Plan. 2014, 122, 100-107. [CrossRef]

105. Gaertner, M.; Larson, B.M.; Irlich, U.M.; Holmes, P.M.; Stafford, L.; van Wilgen, B.W.; Richardson, D.M. Managing invasive species in cities: A framework from Cape Town, South Africa? Landsc. Urban Plan. 2016, 151, 1-9. [CrossRef]

106. Buckley, Y.M.; Catford, J. Does the biogeographic origin of species matter? Ecological effects of native and non-native species and the use of origin to guide management. J. Ecol. 2016, 104, 4-17. [CrossRef]

107. La Rosa, D.; Privitera, R. Characterization of non-urbanized areas for land-use planning of agricultural and green infrastructure in urban contexts. Landsc. Urban Plan. 2013, 109, 94-106. [CrossRef]

108. Sanesi, G.; Colangelo, G.; Lafortezza, R.; Calvo, E.; Davies, C. Urban green infrastructure and urban forests: A case study of the Metropolitan Area of Milan. Landsc. Res. 2016. [CrossRef]

(C) 2016 by the authors; licensee MDPI, Basel, Switzerland. This article is an open access article distributed under the terms and conditions of the Creative Commons Attribution (CC-BY) license (http://creativecommons.org/licenses/by/4.0/). 